\title{
ARTICLE
}

\section{RETHINKING TWELFTH-CENTURY VIRTUE ETHICS: THE CONTRIBUTION OF HELOISE}

\author{
Sandrine Berges
}

Twelfth-century ethics is commonly thought of as following a stoic influence rather than an Aristotelian one. It is also assumed that these two schools are widely different, in particular with regards to the social aspect of the virtuous life. In this paper I argue that this picture is misleading and that Heloise of Argenteuil recognized that stoic ethics did not entail isolation but could be played out in a social context. I argue that her philosophical contribution does not end there, but that she departs from both the stoics and her teacher, Abelard, in her defence of the ideal of moderation. By insisting that virtue must strike a mean between two extremes, she shows that Aristotelian virtue ethics were present in the intellectual life of the twelfth century.

Keywords: Heloise; virtue ethics; Seneca; Abelard; Aristotle

\section{STOIC OR ARISTOTELIAN VIRTUE ETHICS? ${ }^{1}$}

A common picture of medieval ethical writings is that virtue ethics as we know it, i.e. Aristotelian virtue ethics, did not find expression in the writings of philosophers before Aquinas. ${ }^{2}$ Thinkers of the Twelfth Century were influenced by the Stoics more than Aristotle and this often meant that their ethical thought was focused on the interior world and the bringing of one's soul in line with God's order. Participation in the activity of one's moral or political community was not encouraged, but instead, the virtuous person was supposed to build a closed, well-ordered interior world along the lines of Stoic recommendations. There are really two claims here, equally disputable. The first is that the

\footnotetext{
${ }^{1}$ I would like to thank the following people for their help in putting this paper together: James Alexander, Paul Kimball, Lars Vinx, Bill Wringe, for their comments, Lucas Thorpe and the audience at the Bogazici philosophy seminar where I presented a version of this paper, Karl Ubl for help in getting hold of some elusive texts for me, and finally the editors and two anonymous referees for the British Journal for the History of Philosophy.

${ }^{2}$ MacIntyre makes this claim in his After Virtue, 168-9. Although MacIntyre is not a medieval historian, this particular point is discussed in Nederman 'Beyond Stoicism and Aristotelianism' as significant.
} 
authors of the twelfth century had insufficient access to Aristotle's text so that their ethical thoughts could not possibly be influenced by his. The second is that Stoic ethics are so unlike Aristotelian ethics that they are not recognizable as what we now call virtue ethics. Both claims have been challenged. Cary Nederman in his several writings on the topic has made a case that the writings of Aristotle that were accessible to twelfth-century readers contained enough of his ethical thought that its readers would both be impressed by the importance of the theory and be able to understand its contents and use them in their own writings. Nederman argues that one twelfth-century writer in particular, John of Salisbury, produced ethical writings that were Aristotelian in the sense that they emphasized the importance of the mean and the avoidance of excess in virtue, as well as the idea that virtue is a firm state of character acquired through habit. ${ }^{3}$ However, Nederman thought John was the exception, rather than the rule, and that a lot of twelfth-century ethics was mostly based on Stoic principles. ${ }^{4}$

In this paper I want to argue that John of Salisbury was not the only twelfthcentury thinker to develop Aristotelian ethical arguments, but that another thinker, twenty years older than John, got there first. That thinker is Heloise of Argenteuil, a highly educated, powerful abbess who was taught by Abelard and later became his wife (until circumstances forced them apart). I do not claim that Heloise gained such great insight from the writings of Aristotle that were available that she would have been able to construct her own Aristotelian ethical system based on a few lines from the Categories, but that plenty of ethical insight was available in the authors we know that she did read - because she quotes them - such as Seneca and Cicero. ${ }^{5}$ Those authors tended to share a lot more with their Greek predecessors than is sometimes recognized. ${ }^{6}$ In particular, the supposed contrast between Stoic isolationism and Aristotle's emphasis on

\footnotetext{
${ }^{3}$ Nederman and Brickmann, 'Aristotelianism in Policraticus', 228. See also Nederman, 'Beyond Stoicism and Aristotelianism'.

${ }^{4}$ Nederman argues that MacIntyre 'captures in brief compass a pronounced tendency implicit in a wide range of scholarship: the view that philosophical ethics during the High Middle Ages was bifurcated between Abelardian (Stoic/Christian) and Aristotelian understandings of natural virtue', pp. 175-6. See also Lapidge, The Stoic Inheritance and Wieland, 'The Reception of Aristotle's Ethics', 657-9.

${ }^{5}$ See Bejczy, The Cardinal Virtues in the Middle Ages, 71, for the claim that Cicero and Seneca were the most widely read authors of the twelfth century, and Bejczy's introduction to his and Nederman's 'Beyond Stoicism and Aristotelianism', 2, for the claim that Cicero's De Inventione was one of the most quoted ancient sources between the twelfth and the fifteenth century, along with Macrobius's Commentary on the Somnium Scipionis. As to Heloise's acquaintance with Seneca's Letters to Lucilius, one need no other evidence than the fact that she quotes it twice in three letters: 40.1 on p. 51 and 24.1 on p. 72 in Levitan, Abelard and Heloise.

${ }^{6}$ In attributing some Aristotelian beliefs to these authors I will follow A.A. Long 'Greek Ethics after MacIntyre' who argues that it is a mistake to understand Stoicism as belonging to a different ethical tradition from Aristotle because both take moral teleology, the idea that there is a human essence and that the good life means developing according to that essence, as their starting point, and both use very similar accounts of virtue, i.e. that which enables us to develop according to our nature or essence. See also for example many of the articles in Sihvola and Engberg-Pedersen, The Emotions in Hellenistic Philosophy.
} 
the role of the community for individual flourishing is clearly mistaken. The Stoics, on the whole, did believe that a virtuous life was best lived in a community, and that the sort of character building required for virtue was helped by the development of good relationships with family, friends, neighbours and dependents. ${ }^{7}$ Secondly when it comes to the Roman philosophers, who were read in the period we are discussing, it is even less plausible to insist that their views were radically different from Aristotle's. As politicians or political advisors themselves, they would have particularly valued the kind of teaching that aimed at better politics. Thirdly it is in any case quite clear that the Stoics did not turn their back on community involvement from the fact that they defended cosmopolitanism, i.e. the view that we each owe our moral allegiance to the entire human race. Moral allegiance is not best cashed out by moral isolation, by concentrating on your own betterment and ignoring the plight of others.

One initial reason why we should take Heloise seriously as a philosopher is that she demonstrated a keen understanding of Stoic ethics. She is, however, a critical reader, one who is not afraid to depart significantly from the philosophers she cites, even if it means going against what her teacher, Abelard, also believed. She is a creative thinker who is able to, using only fragments of Aristotelian philosophy, construct virtue ethical arguments that she can apply to the growth of her religious community. In this essay I mean to focus on two aspects of Heloise's thought which, I argue, contribute significantly to the state of twelfth-century ethics and bring particular insight on what kind of philosophical reflections could be applied to life in a particular kind of community: the nunnery. First, I shall argue, Heloise seems to place greater weight than some of her contemporaries, in particular Abelard for whom ethical goodness is achieved at the level of intention, rather than action, on the view that virtue grows within a community, not in isolation. She derives from the Stoics, via Seneca, a belief in the moral value of one's community and rejects Abelard's belief that the road to virtue is a lonely struggle with oneself. Secondly, Abelard appears to see the virtues as perfect achievements rather than means between two extremes. For instance, in an early discussion of ethics, he appears to favour abstinence over temperance, suggesting that it is better to free oneself completely of the kind of impulses that a temperate person is supposed to resist. ${ }^{8}$ Heloise, on the other hand, seems keen to reinstate the Aristotelian understanding of virtue as a mean between two extremes. In her letters, she defends the ideal of moderation against Abelard's calls for struggle and self-control, and in doing so, she uses the vocabulary of the mean, in very much the same way as John of Salisbury did some years later. ${ }^{9}$ This particular debate, of course, has great implications for Heloise's understanding of what the life of a religious community should be like.

\footnotetext{
${ }^{7}$ See, for example, Seneca's Letters to Lucilius, 9, which I discuss in Section 2.

${ }^{8}$ Theologica Christiana II, 45. This is discussed in Section 3 of this paper.

${ }^{9}$ Both Heloise and John of Salisbury use 'modus' to refer to the mean. Cf. Policraticus 480d and 531c, quoted in Nederman and Brickman, 'Aristotelianism in Policraticus', 214 and Muckle, 'Letter of Heloise', 243.
} 
We have very few surviving texts from Heloise of Argenteuil, and, because they are letters, some might argue that they are not philosophical material. ${ }^{10}$ This would be quite wrong. Several philosophical texts are written in that format, the letters of Seneca, for instance, a particularly relevant analogy as Heloise quotes from them often, and seems to model her style on them. ${ }^{11}$ Around the time the exchange between Heloise and Abelard took place, there was a strong renewal of interest in literary letters, brought on by readings of Seneca's Letters to Lucilius. ${ }^{12}$ Exchanges written in that vein were typically skillfully written, following a certain pattern not unlike those of Seneca's, announcing a theme and then developing it in a rhetorically sophisticated manner. These letters were often intended for a public, and it is quite likely that the letters belonging to the collection were not the only ones exchanged by Heloise and Abelard, but the ones they selected for publication (ibid., 88). Their audience would no doubt have recognized the letters as belonging to the genre of philosophical letters on friendship, and would not have mistaken them for personal love letters. ${ }^{13}$ One obvious disparity between Heloise's letters and those of Seneca is that Seneca was writing to Lucilius as an older man to a younger one, and as a teacher to a student. Heloise is both younger than Abelard and was in her youth taught by him. But that does not give the whole picture. At the time she is writing, Heloise is a mature woman who has become a successful abbess, whereas Abelard is an older man without a job and no prospect in his career either as a teacher or a monk. She may well feel that writing to him as a friend and a philosopher is not entirely beyond what her status permits. Indeed, that she feels she can initiate a correspondence in which she casts herself in the role of Seneca suggests that she must have some confidence that Abelard will welcome the chance to correspond with her as one philosopher to another. The first two letters debate the nature of love, and the responsibilities which come with any relationship of love or caring. ${ }^{14}$ Her third letter is more impersonal. She asks Abelard that he write a rule for the convent of the Paraclete, where she is abbess. It is clear from the way she formulates the demand, outlining several difficulties she has considered, giving examples of why the existing rules will not do, and

\footnotetext{
${ }^{10}$ There is little or no doubt about the authenticity of the letters I am discussing here. Doubts have been raised, of course, but they were put to rest firmly by Marenbon's review of the various arguments in 1997, 82-93, and in Wheeler, Listening to Heloise.

${ }^{11}$ For how Heloise models her letters on Seneca's see Irvine, 'Heloise and the Gendering of the Literate Subject'. Henry West also points out that all we have left of Epicurus is of epistolary nature, and this does not stop us from regarding him as an important philosopher, 'Including Women in Ancient and Medieval Philosophies', x.

${ }^{12}$ Irvine, 'Heloise and the Gendering of the Literate Subject', 90.

${ }^{13}$ Indeed, one thirteenth century editor chose to collect the letters of Abelard and Heloise together with those of Seneca, see Irvine, 'Heloise and the Gendering of the Literate Subject', 90 .

${ }^{14}$ This is discussed by Marenbon, The Philosophy of Peter Abelard, 300, and Andrea Nye, 'A Woman's Thought of A Man's Discipline', 7.
} 
arguing against a universal rule which does not have the potential to mould itself to individual needs, that she is not simply asking Abelard to draft a document as he sees fit, but she is trying to engage him in a philosophical discussion as to how communal life should be ruled. It is not clear that Abelard understood her request as such, as his reply is rather didactic, and fails to take into account her discussion of the place of moderation in the good life and good rule - although he takes some of her points very seriously indeed, and matches her request for a better education of novices before they have to take vows with the requirement that she should teach her nuns Latin, Greek and Hebrew. ${ }^{15}$ Another thing that may confirm our suspicion that Heloise was after a philosophical exchange rather than a rule written for her is the fact that Abelard's written rule did not become the rule of the convent of the Paraclete. Instead, Heloise wrote her own, based on some of Abelard's suggestions, but mostly her own thoughts about what such a rule should be, as spelled out in her last letter to Abelard.

\section{OIKEIOSIS, SENECA ON CROWDS, FRIENDSHIP, VIRTUE AND THE RELIGIOUS COMMUNITY}

In this section, I argue that Stoic ethics is not as distinct from Aristotelian virtue ethics as is sometimes assumed, and that its strong social dimension, as formulated by Seneca, was noticed and put to good use by Heloise.

In his letters to his friend Lucilius, Seneca seeks to exemplify the good stoic life, by sharing reflections, anecdotes, quotes from Epicurus and others, and arguments. In the VIIth letter he argues that crowds should be avoided, that they are damaging to the good character. He describes going to some lunchtime games, and witnessing the slaughtering of gladiators, armed with nothing to protect themselves, for the entertainment of the spectators. Horrified by the crowd's enthusiastic response to this unjust treatment of criminals who should have been hung, but not butchered for entertainment, Seneca writes that 'vice is catching', and that no-one, not even Socrates is totally immune to the movements of the crowd, so that somebody whose moral character is not yet firm had better avoid them altogether. We all have to work on our character, he says, and we need calm and peace to do so. But even one individual can create a disturbance in what we have achieved with ourselves, a rich neighbour can make us envious, someone who is mean-minded can lead us to have mean thoughts. He concludes

\footnotetext{
${ }^{15}$ Latin was of course fairly commonly read in the monastic milieu, but Greek and Hebrew were extremely rare, but because Heloise knew them, Abelard suggested she passes on that knowledge to the nuns she was responsible for, because, he said, it might be useful in interpreting religious texts. See Ziolkowski, Letters of Peter Abelard, 23-4 and Johnson, Equal in Monastic Profession, 46.
} 
with quotes praising the life that is lived for few or even just one person, in opposition to the life lived for the masses.

Having read this letter, one could be forgiven for thinking that Seneca believed that the good life had to be led away from the public, that one could only achieve and maintain virtue if one was alone, or with very few people whom one could trust not to set a bad example. But on closer reading, one sees that this is not what Seneca has in mind. The example he picks is a rather extreme one - not all public gatherings are necessarily vice inducing, in fact, he had expected the one he describes to be different, to be entertaining but not a meaningless display of violence - otherwise he would presumably not have gone. He also makes it clear that this sort of entertainment is new, and that previously spectators may have expected something more enlightening. Almost certainly, he would not feel the same way about a Greek theatrical festival. But the extreme character of his example allows him to illustrate the point that if he, an old man and a stoic, is shaken in his character when he attends such events, those who are younger and less well trained than him do not stand much of a chance of coming out unharmed. For those individuals the advice seems to be: keep your community small, if you want to grow - mixing with others will impede your right development.

But turn to the ninth letter, and it becomes clear that even this cannot be Seneca's meaning or that at the very least, this is a dubious interpretation of it. A wise man is self-sufficient, Seneca says, yet he wants friends, neighbours, associates, a wife, and children. Being content with oneself suffices for a happy life, but not for life itself. Those who believe that the sage will never seek the help or company of others but isolate himself from the world are mistaken: 'The wise man is self-sufficient'. This phrase, my dear Lucilius, is incorrectly explained by many. For they withdraw the wise man from the world and force him to dwell within his own skin ((Ep. IX, 13) 51). The need of the self-sufficient sage for others is not so much a mark of their frailty, but so that they may exercise the virtue of friendship (18Ep. IX, 8). ${ }^{16}$ Self-sufficiency, even when coupled with a clear awareness of the dangers of company, does not mean taking oneself out of the world and living 'in one's own skin'. Seneca is very aware that good life is lived in the world, and that it requires developing a number of appropriate relationships within one's community. His understanding of what it means to be human is really, in that sense at least, not that different from that of the Greeks: a human being flourishes not in isolation but as part of a couple, a family, a circle of friends, and a political community.

The idea that the stoic sage can live in the world and at the same time be self-sufficient is perhaps best understood within the context of that elusive

${ }^{16}$ The text reads ' $n$ e tam magna virtus' which I translate as referring to friendship itself, rather
than, as in the Loeb translation, to the virtues of the wise man in general. See Seneca 46 and 47. 
stoic notion: oikeiosis. Central to the stoic conception of moral development (how does that young man eventually become a sage?) oikeiosis is a natural process whereby one extends one's natural tendencies to self-preservation to an impartial concern for all. ${ }^{17}$ Oikeiosis is hard to translate. ${ }^{18}$ One could say that it is a sort of making oneself at home in the world, first in one's own body, then one's environment: a sort of coming to belong. Animals and young children are capable of the early stages of the process - that of recognizing their own bodies as belonging to them, and learning how to use them for their own survival. Mature animals are also able to engage in later stage of oikeiosis, that of caring for their young. Human oikeiosis starts as it does with animals, but goes further due to human rationality.

Hierocles in a fragment from his Elements of Ethics gives us a vivid image of what oikeiosis looks like, one that was part of orthodox stoicism, and therefore, traces of which we might well expect to find in the later Roman stoics $^{19}$ :

Each one of us is as it were entirely encompassed by many circles, some smaller, others larger, the latter enclosing the former on the basis of their different and unequal dispositions relative to each other. The first and closest circle is the one which a person has drawn as though around a centre, his own mind. This circle encloses the body and anything taken for the sake of the body. For it is virtually the smallest circle, and almost touches the centre itself. Next, the second one further removed from the centre but enclosing the first circle; this contains parents, siblings, wife, and children. The third one has in it uncles and aunts, grandparents, nephews, nieces, and cousins. The next circle includes the other relatives, and this is followed by the circle of local residents, then the circle of fellow-tribesmen, next that of fellow citizens, and then in the same way the circle of people from neighboring towns, and the circle of fellow-countrymen. The outermost and largest circle, which encompasses all the rest, is that of the whole human race. Once all these have been surveyed, it is the task of a well tempered man, in his proper treatment of each group, to draw the circles together somehow towards the centre, and to keep zealously transferring those from the enclosing circles into the enclosed ones ... It is incumbent on us to respect people from the third circle as if they were those from the second, and again to respect our other relatives as if they were those from the third

\footnotetext{
${ }^{17}$ Annas, The Morality of Happiness, 265.

${ }^{18}$ Long, 'Greek Ethics after MacIntyre', suggests 'self-ownership' which includes self-recognition and self-love, 250-63. On oikeiosis see also Gisela Striker, The Role of Oikeiosis in Stoic Ethics; Christopher Gill, 'Did Galen Understand Platonic and Stoic Thinking on Emotions?'.

${ }^{19}$ Seneca, although he does not refer to this passage specifically, uses the image of concentric circles in ep. 12.5, to discuss the passing of time. The fact that the image was still present in Stoic writings suggests that Hierocles' text had been influential. See Ker, The Deaths of Seneca, 336-41, for a discussion of Seneca and the use of the concentric circle image in Roman literature.
} 
circle. [...] The right point will be reached if, through our own initiative, we reduce the distance of the relationship with each person.

(Long and Sedley, The Hellenistic Philosophers, 56G)

Stoic moral development consists in bringing all those circles together, i.e. making one's perception of oneself fit the last of those circles. The self thus grows from a lone disembodied soul, an infant who cannot recognize her own hands, let alone her mother, to a child learning to use her body to survive, and to look after her physical well-being, but who also loves her family, to a young person who has friends, neighbours, associates, and to a mature individual who sees herself as one human being among others, and who recognizes the value of humanity wherever it may be, and however well developed it may be. Thus, the Stoic sage, like Seneca does in letter forty-seven, can claim to eat at table with his slaves, as they are just as human as he is, and their company is nothing to be ashamed of.

I am glad to learn, through those who come from you, that you live on friendly terms with your slaves. This befits a sensible and well-educated man like yourself. 'They are slaves,' people declare. Nay, rather they are men. 'Slaves!' No, comrades. 'Slaves!' No, they are unpretentious friends. 'Slaves!' No, they are our fellow-slaves, if one reflects that Fortune has equal rights over slaves and free men alike.

He goes on to recommend that masters should share their table with slaves, as they would with friends or family, that is, not hold out an open invitation to all of one's slaves - but those whose company we value, just as we would invite some of our neighbours but not all. Again, the emphasis is not merely on respect of humanity in an abstract fashion - although there is that too but on friendship that results in social interaction in the actual world. A twelfth-century philosopher who, like Heloise, knew the letters well, would not necessarily have believed that a wise person had to be cut off from the world, but, if she understood oikeiosis in the manner I have suggested was correct, one should find the right way of engaging with one's community, this interaction being an essential part of one's development. ${ }^{20}$ And even when that development is complete and one has achieved the heights of wisdom, the twelfth-century stoic may understand the importance of practising one's virtues through friendship.

Abelard's own ethics, with its emphasis on the moral priority of intentions is perhaps more of an isolationist model. ${ }^{21}$ Indeed, in the Collationes, he goes so far as to claim that acts themselves are indifferent, that is, they have no moral value

\footnotetext{
${ }^{20}$ See Mews, Abelard and Heloise, 152.

${ }^{21}$ See Marenbon and Orlandi, Peter Abelard, 210.
} 
positive or negative, and that all the value is carried by the intention. Even when Abelard considers the ideal moral community, that is, that republic of Plato understood as a sort of convent for married couples, he requests that the citizens should observe abstinence, thereby seriously limiting their interactions. ${ }^{22}$ For Abelard, moral goodness is very much a property of one's internal landscape rather than of one's interaction with one's community. If there is any activity involved, it is a struggle with oneself, with one's body, but never an effort to fit in with the world, to make a good life for oneself and others within the community. ${ }^{23}$ But this is not what we gather from Heloise's own writings. She does want to focus on the life of her community. Her first letters are concerned with trying to make sense, not of her feelings, not of her internal landscape, but of the situation she finds herself in: what has she done wrong? How can she make her life without Abelard, and in seclusion, tolerable? In her first letter, Heloise encourages Abelard to share his troubles not just with herself, but with the entire convent, because 'A community of grief can bring some comfort to one in need of it, since many shoulders lighten any burden or even make it seem to disappear. ${ }^{24}$ She thus proposes that managing our emotions - a central stoic concern if ever there was one - is best achieved through community engagement. The solution to Abelard's suffering is not to retire, alone, and build a wall around himself while he struggles with his feelings to make them disappear, but to open himself up and request help from the community that considers him as their father (Abelard founded their convent and instituted himself as their spiritual advisor), so that they may help him by sharing his burden.

In her last letter, having promised Abelard not to dwell anymore on her feelings and her dissatisfaction with her fate, she chooses to focus not on her inner landscape, and how to make it more pleasing to God, but on the organization of life within the convent. How can she and her nuns, together, lead a good and fruitful life? Is it possible to replace rules that hamper their progress, with new ones that favour the qualities and strengths that stem from their specific nature? This interest in improving the communal life of the nuns by choosing better suited activities for them may seem out of line with the idea that the point of convent life was simply to hide oneself from the world and be closer to God. When Peter the Venerable, writing to Heloise and expressing his wishes that she would come to Cluny, near him, or the 'joyous prison of Marcigny' nearby, the picture he offers of convent life is a rather more passive one:

You would watch young girls of God, stolen as it were from Satan and the world, erecting high walls of virtue on the bedrock of their innocence and

\footnotetext{
${ }^{22}$ Marenbon, The Philosophy of Peter Abelard, 245 and 306. I will discuss Abelard's take on Plato's ideal city in the next section.

${ }^{23}$ See Marenbon and Orlandi, Peter Abelard, 129-30.

${ }^{24}$ Levitan, Abelard and Heloise, 51; Muckle, 'The Personal Letters Between Abelard and Heloise', 68. This passage echoes one in Seneca's in which he claims that true friends 'have all things in common, especially their troubles' 6.3 .
} 
raising to the very heights of heaven the rooftop of a blessed edifice. Your heart would smile to see them flower in angelic chastity in company with the most virtuous of widows, and all of them alike awaiting the glory of that great and blessed resurrection, their bodies enclosed so snugly in their houses as if already in a tomb of blessed hope.

(Levitan, Abelard and Heloise, 269. Constable, The Letters of Peter the Venerable, v1, ep.115, 306)

The nuns of Marcigny are portrayed as reclining, as in a grave, waiting for death to take them. Heloise, though she may disapprove of certain forms of activity and participation for her nuns, such as working the harvest, does not recommend that they should be inactive, but that work more suited to their strengths and nature be found. Similarly, though she suggests that the duty of hospitality should not be imposed on her nuns, the justification she offers is not that nuns should never see any outsiders, but that they should avoid the risks presented by the dining and wining together with male guests.

Then what does it imply for a convent of women that the abbot himself is required to read the lesson from the Gospel before proceeding to the hymn? And what about the abbot's table where he is required to dine with pilgrims and guests? Will either be suitable for our religious practice - that an abbess never offer hospitality to men, or that she sits and takes her meals with her male guests?

(Levitan, Abelard and Heloise, 107; Muckle, 'Letter of Heloise', 243)

Both Abelard's proposed rule for the Paraclete, and Peter the Venerable's description of the nuns at Cluny suggest that nuns were expected to be cloistered, cut off from the world both in the sense that they should not have visitors or leave the convent themselves. Indeed, it seems as though Heloise herself is requesting something of the sort when she tells Abelard that entertaining guests over dinner is a risk she does not wish her nuns to take. But such cloistering was not very closely observed and nuns typically did go in and out of their convent homes to work with the community, or take part in religious business in different places. ${ }^{25}$ Even without leaving the convent, however, nuns were exposed to communal life, at least as much as a person living outside a convent would be, simply because they lived together, and because, if they were to avoid too many outsiders, they had to organize the necessities of their survival themselves. A convent was in some ways a small polis, with its own government - the Abbess - and

\footnotetext{
${ }^{25}$ Johnson, Equal in Monastic Profession, observes: 'If we put clerical theory and legislation to one side, however, we can see that the nunnery walls served communities as permeable membranes rather than watertight seals. Neither active nor passive cloistering was absolute: religious women commonly left their houses on all sorts of errands, and those who were not community members entered the monastery precincts on all sorts of pretexts.' 152 .
} 
with each of its members having a specific role to play. It seems therefore that nuns - and indeed monks - would have been in an especially good position to understand that virtue had to be developed within a social context. ${ }^{26}$ As a woman in charge of a group of women living together and interacting, as a group, with the outside world, whether it be those who lived on the land they owned, or the church officials they dealt with when they needed to expand, Heloise would have been well aware of the impossibility of divorcing virtue from one's interaction with various communities.

\section{MODERATION, EQUITY AND THE CONVENT RULE}

As I suggested in my introduction, Heloise's reading of Seneca is not uncritical. She departs from him radically on the question of moderation. In his Letter 85, Seneca attempts to refute the Peripatetics' claim that the happy life is best achieved through moderation: 'This halfway ground (mediocritas) is accordingly misleading and useless', he concludes. Would we seek a middle point as far as good health was concerned? (Ep. 85.9, 290 and 291). ${ }^{27}$ And if not, why suppose that this would be desirable as far as virtue is concerned? (Ep.85.9 and 85.4.). This rejection of the Greek's idea of moderation is also to be found in the writings of Augustine who defines temperance as the pulling out and destroying of the 'lower' desires (De Musica, VI, xv, 50 and De Continentia, 2). Abelard, in his early ethical writings at least, seems to follow the same road as Seneca and Augustine, reading the same interpretation of the virtue of temperance, that is, stripped of moderation, back into the Greeks, attributing to them the ideals of (sexual) self-restraint and even abstinence:

[The philosophers] set up (in the way commended by the Gospels) a life of sexual self-denial (continentium vitam), both for married couples and for the rulers, when they set out a plan for life in the cities as if they were convents for married couples, and when they defined how the rulers of those republics should behave, and when they exemplified in themselves the life of sexual

\footnotetext{
${ }^{26}$ This is something that appears to have escaped the notice of some philosophers and theologians of the twelfth century who concentrated instead on the 'inner motives of moral agents'. Laemers, Claustrum Animae, 128. In that paper, Laemers discusses primarily the theological virtue of caritas, showing how Hugh of Folieto's Claustrum Animae presents it as a social virtue. Thus it cannot be argued that there is only a conflict between internal and external virtue because we are talking about different kinds of virtues, i.e. theological virtue on the one hand, and ethical virtue on the other, where it makes sense to think of the one as internal and the other as socially oriented.

${ }^{27}$ Seneca's use of 'mediocritas' is echoed by Boethius's translation of 'tou metrion' as 'mediocris' in the Topics 107a11-13. Cf. Nederman and Brickman, 'Aristotelianism in Policraticus', 212.
} 
self-denial and abstinence (continentium atque abstinentium) which now is followed by clerics and monks.

(Theologia Christiana, II.45. tr. Marenbon, The Philosophy of Peter Abelard, 306) ${ }^{28}$

It is interesting that although Abelard is talking about the continent individual, he does not use 'temperantia' to describe him, but talks, rather, of abstinence. Both Heloise and Abelard were familiar with Cicero's De Inventione in which he defines temperance as the firm and moderate (firma et moderata) control of sexual and other problematic instincts through reason (De Inventione, II, 164).

From this definition, Abelard retains the focus on the sexual, but drops moderation altogether. For him, as for Augustine, what matters is that we should be firm with our sexual instincts, that we should uproot them altogether if we can there is nothing moderate about that. Both Heloise and Abelard would also have been familiar with Aristotle's doctrine of the mean. In the Categories and the Topics, available to them through Boethius, they would have read Aristotle's exhortations that we should avoid excess (superabundantia) and seek the mean (mediocres) in order to become virtuous. ${ }^{29}$

In her third letter, in which she agrees to stop writing about her personal, emotional and spiritual struggles, as they disturb Abelard, Heloise asks that they can together come up with a rule for her convent. The rationale behind this request is that the existing (Benedictine) rule, written for men, cannot be applied to nuns without creating unnecessary discomfort and practical difficulties. Marenbon sees this call for moderation as one for consolation and help in bearing what Heloise sees as her - and by extension all women's - essential weakness (Marenbon, The Philosophy of Peter Abelard, 311). She cannot simply strive to become more virtuous, she is incapable of earning a 'victor's crown' by going to war against herself, or to earn more than the "corner of heaven God places me in'. ${ }^{30}$ For Marenbon, Heloise is simply calling Abelard back to reality, pointing out to him that for most people, perfection is not a realistic goal, and that they need help dealing with hardships and difficulties, especially if they are living as recluse in a convent. I disagree with his assessment, and I believe that there is more philosophical content in Heloise's arguments.

It may help perhaps to clarify the context of the passages Marenbon refers to. True, Heloise is asking for consolation, she is asking for help coping with convent life, and she is asking Abelard that he not see her as stronger than

\footnotetext{
${ }^{28}$ It must be noted that this is a relatively early text and that Abelard is more concerned in that text with showing that ancient doctrines were not incompatible with Christianity. Perhaps, therefore one ought to accuse him of vagueness rather than misunderstanding.

${ }^{29}$ This is discussed by Nederman and Brickmann, 'Aristotelianism in Policraticus', 212. In that article, the authors argue that John of Salisbury embraced this and other ethical doctrines of Aristotle, long before the rediscovery of the Ethics. Indeed, Abelard wrote his own commenrary on the Categories. Marenbon, Boethius, 167.

${ }^{30}$ See full quote on p. 679 .
} 
she is. But there is an unmistakable ring of confidence to her writing that does not chime well with a literal interpretation of these demands. The letters are clearly written by somebody who is not short of resources that would help her cope with a secluded life. Moreover, although she and her nuns almost certainly did need external help in setting themselves up, and securing even the bare necessities of convent life - purchasing food and clothing, acquiring bibles and other religious texts, dealing with the monks who said mass and gave them communion, organizing their rites - she is not quite as helpless as it may seem from those letters. Heloise was in fact a highly capable abbess who was extraordinarily successful in expanding her abbey (acquiring several sister houses) and educating her nuns (she taught them Greek and Hebrew). So we should take her pleas for help with a pinch of salt, perhaps. But one thing she may have needed from Abelard, that she could not easily find anywhere else, within or without the convent, was an interlocutor, someone who was her equal, and with whom she could engage in the kind of intellectual and philosophical exchange that she craved. So when in the fifth letter, she agrees to stop talking about her emotional turmoil, and asks instead that he write for her a convent rule, she is not merely asking him to produce a document, as he sees fit. She is asking him to engage with and respond to some thoughts she puts forward on the good life in general, and the religious life in particular. These thoughts include a wider view of what it means to be virtuous which seems to be in almost direct conflict with the view put forward by Abelard earlier.

Heloise first takes issue with Abelard's conception of virtue in the third letter:

Do not talk to me of strength, or fighting the good fight. Do not tell me that power is made perfect by weakness, and that no one is crowned who does not strive. I seek no crown of victory - enough that I keep from risk, far safer to keep from risk than to keep struggling in these wars. Whatever corner of heaven God may grant will fit me well enough.

(Levitan, Abelard and Heloise, 83; Muckle, 'The Personal Letters Between Abelard and Heloise', 82)

Heloise has no interest in extreme virtue, she does not wish to wage war against herself or compete for a crown, but will be satisfied with safety from vice and 'any corner of heaven' God chooses to grant her. For Abelard, virtue is a struggle with oneself, a competition, and a journey that has a clear completion: once you have succeeded, you are crowned, and you go to heaven. Although he did greatly admire the ancients, we saw that he followed Augustine and Seneca in preferring virtue to be free of moderation. ${ }^{31}$ I believe that much of what Heloise does in her third

\footnotetext{
${ }^{31}$ See Bejczy, The Cardinal Virtues in the Middle Ages, 137, Marenbon, The Philosophy of Peter Abelard, 284-7, and Mews, Abelard and Heloise, 106 for discussions of Abelard's admirative, but also mixed attitude to pagan virtue.
} 
letter is to propose a revision of Abelard's conception of virtue, one that is more in tune with ancient theories. What this means is that whether she refers to her own weakness, or that of women in general, or even weakness of the age, she is not asking Abelard to be more realistic about what she and others can hope to achieve, but trying to persuade him to reinstate the ideal of moderation. To be moderate involves a certain amount of caution which is not necessarily compatible with a constant struggle for perfection. It also involves a recognition of all aspects of what it means to be a human being, and a respect for one's humanity which entails that one should take seriously the demands of the body and of human emotions.

The request for a rule is phrased as follows. Heloise asks Abelard on behalf of the nuns of the Paraclete is that he should:

institute a rule for us to follow, a written directive suitable for women, detailing in full the condition and habit of our own way of life. This has not been done by any of the fathers, and because of this failure, it is now the case that both men and women are received into monasteries to profess the same rule, and the same yoke of monastic regulation is laid upon the stronger and the weaker sex alike.

(Levitan, Abelard and Heloise, 106-7; Muckle, 'Letter of Heloise', 242)

She adds of the Benedictine rule, which she has attempted to follow, that 'as this rule was written only for men, its instructions can be followed only by men'.

A series of examples follows. The Benedictine rule specifies how many pieces of clothing of each kind a monk should have. These, however, Heloise points out, are men's clothes, so this rule is useless for women. Moreover, Benedict recommends that monks wear the woollen clothes directly, i.e. with no underwear. But this is hardly practical, she says, for women who are having their period. Other aspects of the rule which are hard for women to implement are that of hospitality - nuns cannot easily welcome men guests at dinner - and working the harvest - for various reasons, it is harder for nuns to go about outside the convent, and in any case, frowned upon. One amusing example she gives is related to wine: women, she says, quoting Aristotle, can drink more than men without getting drunk, thanks to the monthly 'purgation' of their body. Therefore, we need not limit the quantities of wine they are allowed to drink in the same degree as we limit the monks.

The examples above might give the impression that Heloise is merely concerned with solving a few practical issues. It is certainly true that she takes as her first premise her observation that all is not well in the practical arrangements made for the nuns of her convent. However that is far from being all that she is doing and the import of her discussion is both philosophical - she is asking Abelard to take the ideal of moderation more seriously - and applied in a more significant manner - a central argument she makes is that nuns need to receive a decent education before they take 
their vows. Her observation of the shortcomings of the arrangements in place for her nuns is followed by a statement of the philosophical importance of moderation in virtue:

If discretion is the mother of all virtues and reason the mediator of all good, can something be a virtue or a good which seems so at odds with discretion and with reason? Virtues that exceed the mean should be counted among the vices, Jerome says.

(Levitan, Abelard and Heloise, 109; Muckle, 'Letter of Heloise', 243) 32

This passage is a direct rebuttal of Abelard: if something is not a mean between two extremes, she says, but instead is itself an extreme, then it cannot be a virtue. ${ }^{33}$ The rule itself must be moderated according to the rule maker's perception of his or her subjects' capacities. A rule that ignores what can and cannot be done, and the circumstances in which something can be done either well or poorly is not a good rule. This attitude she observes, is not absent from the spirit of the Benedictine rule.

Saint Benedict himself was consistently aware of the importance of careful distinctions, steeped as he was in the spirit of all things just. In fact, he tempered everything in the Rule to suit the character of the person involved and the season of the year, and in one passage concluded, 'Let all things be done in moderation'. Beginning with the abbot himself, he instructed him to preside over his subordinates 'according to the character and understanding of each, adjusting and adapting himself to all in such a way that he may not only suffer no loss in his flock, but may even rejoice in its increase', and later continued: Let him always keep his own frailty before his eyes and remember not to break the bruised reed ... Let him be discreet and moderate (discernat et temperet), bearing in mind the discretion of Jacob, who said, 'If I should cause my flocks to be overdriven, in one day they all will die.' Following this and other examples of discretion, the mother of virtues, he should temper all things in a way that the strong may have something to strive for and the weak may not be discouraged.

(Levitan, Abelard and Heloise, 110; Muckle, 'Letter of Heloise', 244)

Frailty, she says, quoting Benedict, is not something to be fought, to be overcome, but to be observed and taken into consideration when devising a course of action. 'Do not break the bruised reed', always be moderate and bear in mind the character and intelligence of those you rule, before instructing them. These comments are not just concerned with moderation, but also

\footnotetext{
${ }^{32}$ Sed et cum omnium virtutum discretio sit mater, et omnium bonum moderatrix sit ratio, quis aut virtutem aut bonum censeat quod ab istis dissentire videat? Ipsas quippe virtutes excedentes modum atque mensuram, sicut Hieronimus asserit, inter vitia reputari convenit.

${ }^{33}$ The use of Jerome here is clever, as so many of Abelard's own prescriptions are drawn from Jerome. See Bussell in Wheeler, Listening to Heloise, 246 for a discussion of this passage and its impact.
} 
with the particularistic nature of virtue. How one goes about acquiring a particular virtue depends on one's existing nature. Courage is not exemplified by the same course of action in the young and fit on the one hand and the old and frail on the other. Nor will it be the same in those who are by nature shy or timid, and those whose instinct is to run in the face of danger. The mean has to be found for each individual according to the instincts they have to moderate.

It is in this context that we must read Heloise's references to the weakness of women: she is simply trying to extend the equitable conception of pastoral care that Benedict seems to have adopted to women as well as men. Though she refers on several occasions to women's weakness, the examples of difference she gives seem to be down to physical constitution (women bleed once a month, men do not and women can drink without fear of getting drunk, but men cannot, men can engage in more demanding physical labour than women) or socially imposed behaviour (women cannot wear men's clothing, they cannot entertain men at dinner without being perceived as flirting with them, and unchaperoned women cannot work in the fields). ${ }^{34}$ To apply a rule which was meant to be equitable to a group of people who have a number of significant characteristics without seeking to change any aspect of the rule goes against its spirit, she says.

Moreover, it goes against the spirit of virtue to seek to impose a mode of behaviour on people when their character is not suited to receive it. A nun attempting to behave in a way that is specifically suited for a man will not be virtuous. If she attempts to use her body beyond its natural capacities, resulting in injury and the inability to perform necessary tasks later, she will not be virtuous. If she flaunts what is socially acceptable for women, shocking people and attracting unwanted attention, without any justification other than the desire to follow a law written for monks, again, she will not be virtuous. ${ }^{35}$ Such behaviour is excessive, and excess is a characteristic of vice, not virtue. Obeying the law may be virtuous, but failing to see that there are circumstances in which the universal character of the law fails to accommodate successfully the particulars of the situation is to be blind in a way that a virtuous person is not supposed to be - it is a failure of the fine judgement which is supposed to be typical of the virtuous person. Similarly, a rule giver who does not take into account the particular characteristic of his or her subjects when writing laws and who does not allow for the

\footnotetext{
${ }^{34}$ Andrea Nye argues that although Heloise starts off discussing the weakness of women, she moves on to questioning 'any moral order based on law, commands and obedience' (A Woman's Thought of A Man's Discipline, 10). My own claim, slightly weaker, is that like Plato and Aristotle, Heloise points to the need of supplementing law with equity.

${ }^{35}$ This is not to say that one could not behave in that very way for different reasons, to shock people into reflecting on gender questions, to challenge their prejudices, or even to prove a point about shortcomings of the existing rule.
} 
practice of equity, i.e. ruling against the law when the circumstances clearly demand it, is not a good ruler.

Those arguments could almost be directly lifted from Aristotle's Rhetoric, and his views on equity, or, equally, from Plato's Statesman, and his argument that an ideal ruler would sit by each subject, and assess his or her needs in terms of his or her character, and prescribe a rule of conduct accordingly. Heloise was almost certainly not familiar with those texts, however, we know that the arguments of the ancients had found their way to Medieval scholarship, through various commentaries. ${ }^{36}$ In particular, Seneca and Cicero's account of clementia is at times very reminiscent of Aristotelian equity. In De Inventione, Cicero describes clementia as a part of temperance, though he sees it as moderation through courtesy of the hatred one may feel for someone. ${ }^{37}$ Seneca, in his infamous discussion of young Nero's clemency, on the other hand, does make clementia sound something like equity, the exercise of mercy when particular circumstances justify it, or when it seems that strict application of the law would have unjust consequences. ${ }^{38}$ In fact, that it depends on choice which is based on the recognition of individual characteristics of a situation, rather than plain duty, is exactly what makes it a virtue. Equity is about helping each individual achieving virtue in the best way they can, taking into account that we are all different, and therefore likely to respond best to slightly different treatments.

While Heloise is certainly concerned with making the life of her nuns more comfortable as well as more religiously correct - in particular she does not see the need of pointlessly punishing the body by engaging in practices that were designed for people of different physical nature - her arguments take us much further than that. Part of what she is saying is that a person's nature should be prepared to receive the religious rule. She is not simply thinking that we all have slightly different natures, different strengths, but that our nature and strengths are not properly realized unless we have received a certain degree of education. She asks whether it is sensible to

test the constancy of the women we accept through the probation of just a single year? Or to instruct them with just three readings of the Rule, as the

\footnotetext{
${ }^{36}$ Cicero's De Inventione, and Macrobius' Comentarii in Somnium Scipionis being the most frequent references to ancient theories on the virtues, Becjczy, in Becjczy and Newhauser, 2. Reading Heloise's quotation from Jerome, it is hard to believe that Jerome himself was not familiar with Aristotle's theory of the virtues - again, perhaps not directly, but at the very least through other writers.

37. Clementia, per quam animi temere in odium alicuius iniectionis concitati comitate retinedur', II, 164.

${ }^{38}$ It is probably this understanding of clementia which has led Syme, Tacitus, 338, to claim that clementia was not a virtue because it depended on choice and whim, not duty. Fuhrmann, Die Alleinherrschaft und das Problem der Gerechtigkeit, suggested that clementia was best understood as derived from the legal concept of aequitas, the principle of particular justice. See also Konczol, 'Clemency and Justice' for a discussion of the legal elements of De Clementia.
} 
Rule itself prescribes? What can be more foolish than entering on a path that is both unknown and as yet unexplained? Is there any more presumptuous act than committing yourself to a way of life you do not know or taking vows you have no capacity to fulfill?

(Levitan, Abelard and Heloise, 109; Muckle, 'Letter of Heloise', 243)

She is referring to the typical convents' recruitment policy. Nuns would of course start off as novices, and then after a year, take the vows. The only 'instruction' they would receive beforehand was three readings of the Rule. ${ }^{39}$ None of this, Heloise says, is sufficient to ensure that the recruits know what they are embarking on and are in a position to fulfil their role once they have taken the vows. This is not, it seems, an argument that applies only to women, but Heloise appears to be questioning the Benedictine rule itself. No-one should commit themselves to spending the rest of their lives in a convent or monastery who does not understand what it involves. A woman coming in as novice, unless she had been sent to the convent to be educated as a child, had probably received next to no education. And if all that was expected of her before she took her vows was three readings of the Rule (presumably, the rule would be read out to her, and she need not show signs of having understood), she would remain ignorant throughout her life.

It is clear that Abelard pays heed to Heloise's recommendation, and that he has no objection to women being well educated. The Rule for the Paraclete, as Abelard writes it in the last letter, indeed recommends that the nuns of the Paraclete learn Greek and Hebrew as well as Latin, claiming that it will be useful to compare translations of religious texts and that it will be easy for them to learn as Heloise can teach them. He therefore recommends for them an unusually high level of learning, such as would not be found in any convent or in many monasteries. From the example of Heloise, he sees the value of women receiving an education, both for their own sake and for the sake of the service to the church they can then deliver. To be a good nun is to understand sacred texts, and that cannot be done through ignorance. Even if Abelard needs Heloise to remind him of the value of moderation, he needs no such reminder when it comes to reason and knowledge. One cannot be virtuous - and therefore contribute to the life of the convent if one is not educated. And that is not to be understood as merely literate, but as having achieved a degree of excellency as close as possible to Heloise's own, famous as she was for her learning.

\footnotetext{
${ }^{39} \mathrm{Of}$ course if they had been educated at the convent before entering it as a novice, things were different. But that was not the case for all novices, and indeed, by the mid-twelfth century, the practice of sending little girls to convents for schooling purposes was discouraged. See McNamer, The Education of Heloise, 22.
} 


\section{CONCLUSION: WOMEN AND VIRTUE ETHICS?}

It should perhaps come as no surprise that one of the few twelfth-century philosophers who took seriously the ancients' claims about the virtuous life being one that requires a constant adjustment of the self to the community and of the community to the self, rather than an interiorist strict rule following, was a woman and a nun. Even in recent years virtue ethics has held a special appeal to women philosophers, who saw perhaps a justification of their own resistance to a strict application to the moral law which took no account of the particulars of a situation, and in particular, of the relationships involved. This is why Annette Baier, for instance, saw Gilligan's work on women's moral psychology, In a Different Voice, as modern interpretation of Aristotelian virtue ethics ('What do Women Want in a Moral Theory', 263).

In Heloise's case, it is perhaps the fact that she is a professional, whose duties involve caring for a group of nuns, which meant that her philosophical reflections would turn to ethics, rather than the metaphysics she was trained for by Abelard, and that she would have greater ease in understanding how the Stoics had meant for their views to translate to the good life. She is perhaps one of the first applied ethicists (unless one counts all of the ancient philosophers, which may not be unjustified), and interestingly, in the light of the scorn that is sometimes poured on applied ethics, the professional engagement of her philosophy means that she gets the detail of the theory right when Abelard, the purely theoretical ethicist does not.

Submitted 12 June 2012, revised 25 September and 19 November, accepted 13 December

Bilkent University

\section{BIBLIOGRAPHY}

Annas, Julia. The Morality of Happiness. New York: Oxford University Press, 1993.

Augustine. De Musica, liber VI. Jacobsson, ed. Stockholm: Almqvist \& Wiksell International, 2002.

Baier, Annette. 'What Do Women want in a Moral Theory?'. In Virtue Ethics, edited by Roger Crisp and Michael Slote, 262-77. Oxford: Oxford University Press, 1997.

Bejczy, Istvan P. The Cardinal Virtues in the Middle Ages. Leiden: Brill, 2011.

Bussell, Donna Alfano. 'Heloise Redressed: Rhetorical Engagement and the Benedictine Rite of Initiation in Heloise's Third Letter', In Listening to Heloise, edited by Bonnie Wheeler, 233-53. New York: Palgrave Macmillan, 2000. 
Cicero. De Inventione; De Optimo Genere Oratorium; Topica. Translated by Hubbell. Cambridge, MA: Harvard University Press, 1949.

Constable, G., ed. The Letters of Peter the Venerable. Cambridge, MA: Harvard University Press, 1967.

Fuhrmann, M. 'Die Alleinherrschaft und das Problem der Gerechtigkeit (Seneca: De Clementia)'. Gymnasium 70 (1963): 481-514.

Gill, Christopher. 'Did Galen Understand Platonic and Stoic Thinking on Emotions?'. In The Emotions in Hellenistic Philosophy, edited by Julia Sihvola and Troes Engberg-Perdersen, 113-148. Dordrecht: Kluwer, 1993.

Irvine, Martin. 'Heloise and the Gendering of the Literate Subject'. In Criticism and Dissent in the Middle Ages, edited by Rita Copeland, 87-114. Cambridge: Cambridge University Press, 1996.

Johnson, Penelope. Equal in Monastic Profession. Chicago: University of Chicago Press, 1991.

Ker, James. The Deaths of Seneca. Oxford: Oxford University Press, 2009. Konczol, Miklos. 'Clemency and Justice in the De Clementia of Seneca'. Iustum Aequum Salutare IV, no. 4 (2008): 61-9.

Laemers, Jeroen. 'Claustrum Animae: The Community as Example for Interior Reform'. In Virtue and Ethics in the Twelfth Century, edited by Istvan P. Bejczy and Richard G. Newhauser, 119-32. Leiden: Brill, 2005.

Lapidge, Michael. 'The Stoic Inheritance'. In A History of Twelfth Century Western Philosophy, edited by Peter Dronke, 81-112. Cambridge: Cambridge University Press, 1988.

Levitan, William, trans. Abelard and Heloise, The Letters and Other Writings. Indianapolis: Hacket, 2007.

Long, A. A. 'Greek Ethics after MacIntyre and the Stoic Community of Reason'. In Stoic Studies, edited by A. A. Long, 156-78. Berkeley: University of California Press, 1996.

Long, A.A., and David Sedley. The Hellenistic Philosophers, Vol. 1. Cambridge: Cambridge University Press, 1987.

MacIntyre, Alasdair. After Virtue. London: Duckworth, 1981.

Marenbon, John. The Philosophy of Peter Abelard. Cambridge: Cambridge University Press, 1997.

Marenbon, John. Boethius. Oxford: Oxford University Press, 2003.

Marenbon, John, and Giovanni Orlandi. Peter Abelard: Collationes. Oxford: Clarendon Press, 2001.

McNamer, Elizabeth Mary. The Education of Heloise. Lampeter: Edwin Mellen Press, 1991.

Mews, Constant. Abelard and Heloise. Oxford: Oxford University Press, 2005.

Muckle, Joseph Thomas. 'The Personal Letters Between Abelard and Heloise: Introduction, Authenticity and Text'. Medieval Studies 15 (1953): 47-94.

Muckle, Joseph Thomas. 'The Letter of Heloise on Religious Life and Abelard's First Reply'. Mediaeval Studies 17 (1955): 240-81. 
Nederman, Carl, and J. Brickmann. 'Aristotelianism in John of Salisbury's Policraticus'. Journal of the History of Philosophy 21, no. 2 (1983): 203-29.

Nederman, Carl. 'Beyond Stoicism and Aristotelianism: John of Salesbury's Skepticism and Twelfth Century Moral Philosophy'. In Virtue and Ethics in the Twelfth Century, edited by Istvan P. Bejczy and Richard G. Newhauser, 175-96. Leiden: Brill, 2005.

Normore, Calvin. 'Abelard's Stoicism and Its Consequences'. In Stoicism, Traditions and Transformations, edited by Steven K. Strange and Jack Zupko, 132-47. Cambridge: Cambridge University Press, 2004.

Nye, Andrea. 'A Woman's Thought of a Man's Discipline?'. Hypatia 7, no. 2 (1992): 1-23.

Seneca. De Clementia. In Moral Essays, edited by I. Basore. Cambridge, MA: Harvard University Press, 1928.

Seneca. Epistles. Vol, IV, V. Edited by Goold and Translated by Gunmere. Cambridge, MA: Harvard University Press, 1996.

Sihvola, and Engberg-Pedersen, eds. The Emotions in Hellenistic Philosophy. Dordrecht: Kluwer Academic Publishers, 2010.

Strange, Steven K., and Jack Zupko, eds. Stoicism, Traditions and Transformations. Cambridge: Cambridge University Press, 2004.

Striker, Gisela. The Role of Oikeiosis in Stoic Ethics. Oxford Studies in Ancient Philosophy, Vol. I, 145-167. Oxford: Oxford University Press, 1983.

Syme, R. Tacitus. Vol. 2. Oxford: Oxford University Press, 1958.

West, Henry. 'Including Women in Ancient and Medieval Philosophies'. In An Unconventional History of Western Philosophy, edited by Karen J. Warren, xi-xiii. Lanham: Rowman and Littlefield, 2009.

Wheeler, Bonnie. Listening to Heloise. New York: Palgrave Macmillan, 2000.

Wieland, Georg. 'The Reception of Aristotle's Ethics'. In Cambridge History of Late Medieval Philosophy, edited by Norman Kretzmann, Anthony Kenny, and Jan Pinborg, 657-72. Cambridge: Cambridge University Press, 1982.

Ziolkowski, Jan. Letters of Peter Abelard: Beyond the Personal. Washington, DC: The Catholic University of America Press, 2008. 